\title{
Parent's Language Policies and Language Attitudes in The Family
}

\author{
Hayati Nupus ${ }^{1}$, Riandi $^{2}$
}

${ }^{1}$ Universitas Katolik Indonesia Atma Jaya

2 English Education Department, Teacher Training and Education Faculty, University of Mathla'ul Anwar Banten

\section{ARTICLE INFO}

Keywords:

Parent's Language

Policies

Language Attitudes

\begin{abstract}
As citizens of Indonesian society, we should maintain the nation's culture, one of which is cultural heritage, namely the local language or language of each family in Indonesia. So that we as the nation's successors continue to take part in the maintenance and preservation of cultural heritage as a reflection of our identity as children of the nation. The relationship in which education in the family is the goal of national education so that the role of various parties is needed, such as; Teachers, government, facilities and infrastructure, and parents. The aims to be reached in writing this research are; the family language policy adopted by parents at home; Languages coexist (or lose, or gain) in their family environment; the efforts do parents make in learning and maintaining language in their homes. This study uses direct observation methods on the research subject, namely parents. The observations were made in the realm of the family (at home). The data obtained is in the form of a list of statements in the form of the respondent's characteristics, the respondent's response. Interviews in the form of questions and answers about language attitudes and assessment of language and language maintenance. The family language policy implemented by parents at home is frequent, meaning that based on the above percentage results, the policy regarding the language used by parents at home shows "Often" with an overall average percentage value of $50 \%$ or half of the expected $100 \%$ reviewed from the aspect of the language policy adopted; Language beliefs or ideologies, language practice, and language management. This indicates that the language policy adopted at home with the "Frequently" family is used. Meanwhile, based on the above percentage results, the attitude of the language used by the parents at home shows "disagree" with the overall average percentage value of $40 \%$ or $100 \%$ of the expected. Their efforts are to use the local language at home, equip their children with various sources both print and nonprint, and stay in touch with local ethnic groups. To maintain the local language properly, there must be good cooperation between parents, schools, local government, and the community.
\end{abstract}




\section{INTRODUCTION}

In modern society, as today is sometimes very difficult to find a family that still uses their local language, each one is preoccupied with the era of globalization and even carried away by the flow of westernization and westernized culture. As citizens of Indonesian society, we should maintain the nation's culture, one of which is cultural heritage, namely the local language or language of each family in Indonesia. So that we as the nation's successors continue to take part in the maintenance and preservation of cultural heritage as a reflection of our identity as children of the nation. The relationship in which education in the family is the goal of national education so that the role of various parties is needed, such as; Teachers, government, facilities and infrastructure, and parents. However, one of the most important parties is the role of the family, namely parents. (Park, 2013) Heritage speakers acquire an inherited language as their first language through natural input in the home environment and acquire the majority language as a second language, usually when they start school and talk about different topics to people at school, or through exposure through media (written text, internet, popular culture, etc.). Such an approach ' taking into account what families do with language in daily interactions; their beliefs and ideologies about the use of language and language; and their goals and efforts to shape language use and learning outcomes' (King, 2000) Ethnic community organization and family support are important agents of language maintenance.

Families are responsible for passing on their inherited language to the next generation. Research on language policy includes analysis of language beliefs or ideologies (what people think about language); about language practice (what people do with language); and attempts to change or influence these practices through any kind of language intervention, planning, or management (what people try to do with language) (Spolsky, 2004). There is much less focus on solving language 'problems' and a greater emphasis on understanding language policies that are shifting as part of a dynamic social, cultural, and ideological system (Ricento, 2000). However, much of this research continues to focus on language policy and associated language use in public spaces, and in institutional contexts, such as states, schools, and workplaces.

This study investigating the family language of families whose parents have migrated to work so that the inherited language shifts to using other regional languages or even foreign languages when we work abroad or become immigrants, in attitudes or language assessments, namely attitudes that cannot be done, directly observed but demonstrated through real behavior, for example, how people treat speakers of other languages (avoiding, approaching), or in their desire (or not) to learn another language thereby affecting the preservation or loss of the language inherited in that family. (Djamareng \& Jufriadi, 2018), this is also due to the fact, as mentioned above, that language policy has traditionally focused on public and institutional contexts such as school or work, with little regard for the intimate environment of the home and family.

This means that there is an influence on the majority of the languages used by regional languages. Significant gaps also exist in the area of children's language acquisition. For example, basic issues regarding bilingual development including how much and what kind of exposure is needed to ensure balanced bilingualism remains unclear. Other than that, Children's language acquisition scholars have not developed a satisfactory explanation model for why children are raised in the same conditions (for example, with English-speaking fathers and Spanish-speaking mothers. (Park, 2013), each speaking the first language with children) often experience different results. In terms of language proficiency and preference. The area of language policy is traditionally divided into three subareas: status planning (which concerns the function of language), corpus planning (on language forms), and acquisition planning (on language teaching and learning).

From the ideology described above, the author tries to contribute to our understanding of language attitudes and behavior in the face of language shifts, and besides providing insight into how the language ideology of a particular community is very important to the success of legacy 
language programs. To revitalize the language, 'The maintenance and provision of languages that have been carried out in various regions or countries in the world show that the languages used by minority groups and are less influential (prestigious) economically and politically in their communities are threatened by the languages around them' (Bezcioglu-Goktolga \& Yagmur, 2018).

Linguistic minorities experiencing exclusion do not realize that their native language, the legacy of their ancestors, will soon become extinct. Therefore, research has addressed a diverse set of familial language policies, each of which is applied differently and associated with different child outcomes. Researchers have pointed out that factors such as parental consistency in language selection, age, and context are important in determining the extent to which these different language family policies are successful in encouraging the language development of bilingual children (Djamareng \& Jufriadi, 2018). Although neither of these policies has been shown to generate active knowledge of bilingualism on the part of children, research shows that a lack of attention to language planning at home can lead to language shift.

Researchers have pointed out that factors such as parental consistency in language selection, age, and context are important in determining the extent to which these different language family policies are successful in encouraging the language development of bilingual children.

On the occasion of this discussion, several things will be conveyed about previous research that supports the research and the theories that underlie this research. Several previous research studies are briefly described as follows:

1) (King et al., 2008) Family Language Policy. The results show that family language policies are drawn from and contribute to two different fields of study: namely language policy and children's language acquisition, only by taking a comprehensive approach will arrive at a more complete understanding of important cross-disciplinary issues, about how people's language as ideology Parents inform the implementation, realization, and negotiation of family language policies over time as well as the short and long term, short-term effects of such policies on children's language outcomes.

2) (Spolsky, 2004) Language Policy. The results of this study indicate that language ideology or belief refers to the consensus of the speech community about what value is applied to each of the language variables or the variety of named languages that make up the repertoire or the plays or roles that are prepared.

3) (Bezcioglu-Goktolga \& Yagmur, 2018) Second generation home language policy of Turkish families in the Netherlands. The results of his research indicate that the family language policy; Turkish minority families in the Netherlands; choice of language use; the maintenance of language and the shift in language that occurs from with the practice of language in the actions of families according to their ideology, and the management of language involves a deliberate attempt to influence language practice.

\section{Language policy}

Language policy is an increase in the quality of language use, especially the use of language in the family or at home such as regional languages, as quoted (Alwi \& Sugono, 2000) 'The national language policy pays broader and deeper attention to regional languages'. Therefore, the language policy can be carried out by teaching regional languages, taking small steps in the development of the mother tongue or regional language in the family is an important foundation because parents or householders play a very strong role in acquiring children's language. The tendency in our speech society today is that when interacting with other people, they will speak a language that the interlocutors can understand, meaning that each other has clarity and certainly makes them part of the community. Finally, it can make them unable to speak only one language, so without knowing or knowing other languages, for example; if there is someone who has never left his home area until he has a family and has children, that is what causes them to only know or know one regional language, namely their own regional language, he will not know any other language 
except his regional language. However, if the policy is in the family. This means that the role of parents in the house plays an active role and knows the times when parents can decide to become bilingual so that their children are the same. However, if the community or family is closed, it does not deny that they will never build contact with other speech communities, such as the Baduy tribe in Banten, they are one of the tribes that isolate themselves from the outside world. That is what causes them to only know or know one regional language, namely their own regional language. To be bilingual so that the children are too. However, if the community or family is closed, it does not deny that they will never build contact with other speech communities (Indonesian, nd). The people there have an absolute policy regarding language policies that are still in the realm of the family or even with other people the interlocutor still uses their local language. This form of society is a static society that will maintain its condition as a monolingual society.

But people who only speak one language are rarely found today, at least they know two languages even though they do not master the second language as well as the first language, and generally open people will build relationships with other communities with the occurrence of language contact in the phenomenon of language. So what happens from language contacts such as; Diglossia, code mix, code-switching, interference, convergence, and language maintenance (Chaer \& Agustina, 2004).

\section{Language Attitudes}

The behavioral theory assumes that a person's attitude can be known through what he does or does. The link in this study is that Language Attitude shows whether a speaker is happy or not towards a language (Mansyur, 2018); There will usually be a positive attitude in something if it is considered good or liked, while there will be negative if it is considered unkind or disliked. (Kircher \& Fox, 2019) As it is in London, England there is an attitude towards multicultural language there so that it is influenced by such as; individual, mother tongue, educational level, and frequency of multicultural speakers in London England. This means that many factors affect the attitude towards language.

Attitude is so influential and becomes one of the factors in maintaining a language and language shift, furthermore (Grenoble \& Whaley, 2005) as for the language family that is threatened with extinction or the occurrence of language death is caused by one of the world's diversity so that the mother tongue or local language is threatened and language shifts occur. In this case, language maintenance is very important because the attitude towards language plays a role in the continuity and survival of a language in a community in society. As for the relation to language as cultural heritage such as regional languages in China or cultural heritage and the interactive impact of the internalization of western culture and heritage on learning English, where the respondents are students or foreign language learners, there they internalize Western culture more broadly, a more positive view of learning English and more independent, which in turn predicts their confidence in using English. This means that orientation only to foreign languages should not only be on the target culture but also their heritage culture (Lou \& A. Noels, 2018). Things related to policies and attitudes towards language are language preservation, generally in language preservation that occurs in communities such as monolinguals, for example, these communities will be required to be able to maintain and maintain their local language even though they are only a minority speaking community. However, the reality is that it rarely happens because sometimes it is for that kind of thing if you do not have a spoken person to communicate with.

\section{METHOD}

Such as (Spolsky, 2004) (Sicam \& Lucas, 2016), this research is a descriptive study that uses a quantitative approach, which describes language policy and language attitudes in the family, namely using a survey questionnaire method using two questionnaires about language policy: language policy adopted by parents at home and the Language Attitudes survey questionnaire: 
language background or general language attitudes. This quantitative approach is used in discussing quantitative information in the form of attributive frequencies, while the qualitative approach is used for qualitative information accompanied by descriptions of occurrences or phenomena in this study. However, in this study, the qualitative approach is more dominant while the quantitative approach is used as a support to reveal qualitative information. This study using Google Forms to distribute questionnaires.

Primary data from questionnaire sheets that are given directly via google form from social media to respondents. Where the questionnaire contains statements and answers to the checklist that have been prepared is selected, as well as semi-structured interviews conducted with the online google form as well.

Secondary data can be obtained from participants who are married, from young marriages to those who live and live in the place of origin of their hometown, as well as regarding the characteristics of the respondent.

In this study, the policy data for the language adopted or used with children in the home with the family were obtained directly using a questionnaire in the form of a statement, as well as the attitudes of the parents' language towards language regarding their assumptions or views in their use with children in the common house. However, for the efforts made by parents in maintaining their cultural heritage, namely in the form of language using semi-structured interviews.

The data collected is processed;

1) Perform data editing; for the results of the questionnaire to be obtained, it must be edited (edit) first. Then if there is still incomplete data or information, the questionnaire is returned to the respondent to be completed again.

2) Making Code Sheets or Code Cards a code sheet or card is an instrument in the form of columns for recording data manually. The code sheet or card contains the respondent's number and question numbers.

3) Entering Data; namely filling in the columns or boxes of code sheets or code cards according to the answer to each question.

4) Tabulating; namely creating data tables, by the research objectives or desired by the researcher.

However, from all of that the researchers researched Google's online media form in social media because due to the pandemic outbreak, it cannot be done face-to-face.

The population is all respondents (parents). This research is population research because the number of objects to be studied is less than 100. This means that in this study the researcher will examine 20 people (parents) as respondents. However, in this research, the researcher used 20 respondents who participated in the survey and interviews semi-structured. The participants were randomly selected from who experienced young marriage to those who had migrated before marriage in the area where they were born, with various experiences and from different origins, tribes, and ethnicity. On overage, the respondents' age is between 20-30 years, as young parents.

Table 1. The demographic background of the surveyed participants

\begin{tabular}{|c|c|c|}
\hline Component & Category & $\%$ \\
\hline Gender & Male & 38 \\
\hline Education & Female & 62 \\
\hline Bacgkround & Graduate (S2) & 5 \\
\hline & Others & 15 \\
\hline Current & University students & 80 \\
\hline activities & Private compary employee & 20 \\
\hline & Teachers & 50 \\
\hline & Lecturer & 5 \\
\hline & Cinil servart & 10 \\
\hline Age & $18-19$ & 10 \\
\hline (Years old) & $20-25$ & 50 \\
\hline & $26-30$ & 15 \\
\hline & $31-40$ & 10 \\
\hline & $41-50$ & 15 \\
\hline
\end{tabular}


The data of this study are in the form of language policies adopted and attitudes towards language in family language maintenance, summarized in the respondents' answers (as parents) in the questionnaire. The questionnaire used in this case is closed, namely a questionnaire that has provided the answer so that the respondent just chooses and answers it directly by the respondent. This method is used to collect data from respondents regarding language policies in families and their attitudes towards language. Besides, the question items asked and alternative answers are provided. Therefore, the questionnaire data is in the form of qualitative data, it needs to be converted into quantitative data using numeric symbols.

In this study, the researcher carried out the survey method, the study of survey methods as a field of applied statistics concentrating on human-research surveys, so the sampling of individual units from a population (Glott et al., 2010).

This research conducted by questionnaire (statements) and interview semi-structured

This research method using the Questionnaire (statements) instrument. By determining the answer score or the answer value that will be given by the respondent, namely in the variable "Parent Language Policy" and "Attitudes toward Language itself".

The Likert scale is used to measure the attitudes, opinions, and perceptions of a person or group about social phenomena, and the measurement method is used to measure attitudes, opinions, perceptions of a person or group of people about social phenomena. (Bertram, 2013) in his journal states that "The psychometric response scale which is mainly used in questionnaires is to obtain participant preference or level of agreement, with a statement or a series of statements. Likert scale is a non-comparative scaling technique and is unidimensional (only measures one trait). Respondents were asked to indicate their level of agreement with the statements given via an ordinal scale. Likert scale is a method of calculating questionnaires that are distributed to respondents to determine the scale of attitudes or certain objects.

The first part of this survey is the Parental Language Policy questionnaire, with a background in language beliefs and ideology, language practice, language management (Spolsky, 2004), this part of the survey presents a questionnaire in the form of twenty statements. Researchers use Indonesian in the questionnaire to avoid misconceptions when participants fill out a questionnaire in the form of a statement from the first variable, namely the parent language policy. Participants were instructed to respond to items on a 4 -point Likert scale $(1=$ rare, $2=$ sometimes, $3=$ often, and $4=$ always)

The second part of this survey is the modified questionnaire used (Sicam \& Lucas, 2016). This section survey discusses language attitudes, in which respondents are presented with fifteen statements. Researchers also still use Indonesian in the questionnaire to avoid misconceptions when participants fill out a questionnaire in the form of statements from the language attitude variable. Participants were instructed to respond to items on a 4 point Likert scale $(1=$ strongly disagree, 2 = Disagree, $3=$ Agree, and $4=$ strongly agree).

Likert scale: Through adapt and adopt the questionnaire based on the responses of respondents/participants in Indonesian, and shaping the instrument into Google Forms, then distributing the questionnaire via social media, and grouping data based on instrument results using Microsoft Excel. The last, transfer, and calculate data with distribution frequency.

This percentage description analysis is used to examine the variables in this study, namely the variables of parents' language policy and attitudes towards language. The data interpretation stage is processed and used using percentage calculations. The calculation of this percentage is to see the ratio of the size of the frequency of each alternative answer to the questionnaire. 
The percentage is obtained by comparing the number of answers to the number of samples associated with the number $100 \%$. Of the 20 people (respondents) who were taken after analyzing the distribution of the questionnaire.

\section{FINDING AND DISCUSSION}

\section{Parents' opinion on language policies used at home in the family}

Parental language policy regarding language opinions obtained and learned, in terms of aspects; language policy (Spolsky, 2004);

a) Beliefs or language ideology: a set of beliefs concerning the use of language and language

b) Language practice: what individuals do when using language (e.g. patterns of their linguistic choice, formality, following agreed or not agreed with rules, etc)

c) Language management: formulation and proclamation of explicit plans or policies, usually but not necessarily written in a formal document, regarding the use of language

Table 2. Parents' language policy used at home in the family

\begin{tabular}{|c|c|c|c|c|c|}
\hline Category & Always & Often & Rarely & Never & Average Score \\
\hline $\begin{array}{l}\text { Plan the use of the vernacular or bcal hnguage with the } \\
\text { children in each family gathering }\end{array}$ & $25 \%$ & $10 \%$ & $75 \%$ & $22 \%$ & 1.65 \\
\hline $\begin{array}{l}\text { Teaching the use of Local hnguages with children to } \\
\text { communicate in the home }\end{array}$ & $23.8 \%$ & $37.5 \%$ & $35 \%$ & $14.3 \%$ & 1.38 \\
\hline $\begin{array}{l}\text { Communicate in extraordinary Local languages rather than } \\
\text { with other languages }\end{array}$ & $16.3 \%$ & $37.5 \%$ & $17.5 \%$ & $10 \%$ & 1.02 \\
\hline $\begin{array}{l}\text { Plan the use of Indonesian with the children in each frmily } \\
\text { gathering }\end{array}$ & $30 \%$ & $75 \%$ & $12 \%$ & $10 \%$ & 1.59 \\
\hline $\begin{array}{l}\text { Teaching the use of Indonesian with children to } \\
\text { communicate in the home }\end{array}$ & $25 \%$ & $25 \%$ & $26.3 \%$ & $22.3 \%$ & 1.23 \\
\hline $\begin{array}{l}\text { Communicate in extraordinary Indonesian rather than with } \\
\text { other knguages }\end{array}$ & $18.8 \%$ & $50 \%$ & $12.5 \%$ & $11.3 \%$ & 1.16 \\
\hline $\begin{array}{l}\text { Plan the use of English with the children in each family } \\
\text { gathering }\end{array}$ & $12.5 \%$ & $75 \%$ & $10 \%$ & $18.8 \%$ & 1.45 \\
\hline $\begin{array}{l}\text { Teaching the use of English with chidren to communicate } \\
\text { in the home }\end{array}$ & $5 \%$ & $27 \%$ & $38 \%$ & $28.5 \%$ & 1.23 \\
\hline $\begin{array}{l}\text { Communicate in extraordinary Engish rather than with } \\
\text { other huguages }\end{array}$ & $7.4 \%$ & $37 \%$ & $6 \%$ & $31.2 \%$ & 1.02 \\
\hline AVERAGE & $20 \%$ & $50 \%$ & $30 \%$ & $20 \%$ & 1.30 \\
\hline
\end{tabular}

Based on the results of the above percentages, the policy on the parental language used at home shows "Often" with an average overall percentage value of $50 \%$ or half of the expected $100 \%$ in terms of the policy aspect of the language adopted; belief or ideology Language, language practice and language management, and 30\% indicate "Rarely" using it in the home with family or especially with children at home. And $20 \%$ for the results with the same percentage level, namely the scale of "always" and "never" with the policy of the parent language used at home. It shows that the policy of the language adopted at home with the family "Often" is used.

Whereas for the average participant/respondent answered more inclined "planning the use of everyday language with regional languages at home with children in every family meeting with the highest first average score, namely 1,65 and planning the use of Indonesian, the acquisition of scores second, namely 1.59 and for planning English use at home with children in family gatherings, the score was 1.45 . With the results of the average total score summed to be 1.30 . So that means the language used is close to all languages but the highest score is the regional language used daily with children, the language used at home with family. 
The policy of the language used or used with children at home, with family, contradicts the language adopted in the family with children, it shows that it contradicts the supporting results that the mean of the overall number score on the scale shows "often", such as chart below;

Chart 1. The distribution of parents' language policy

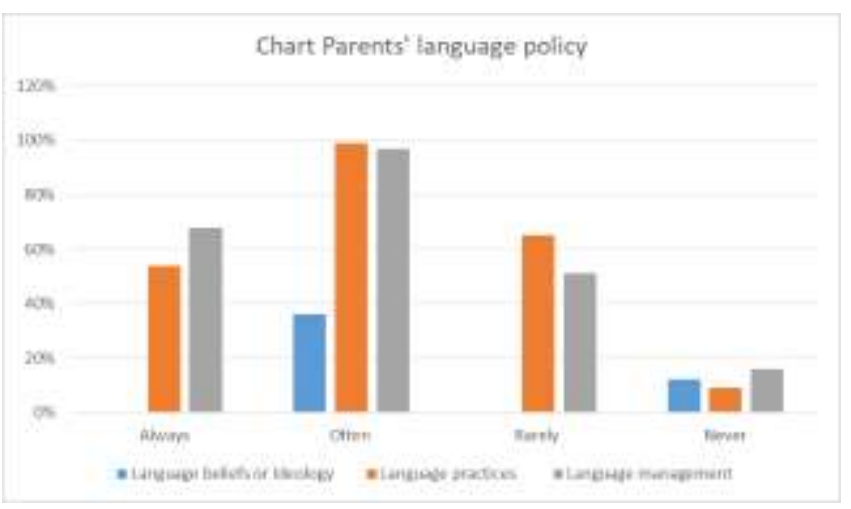

Parents opinion on language attitudes used at home in the family

Attitude is a network of beliefs (cognition) and values that give a person to react or react to an object in a certain way (Chaer \& Agustina, 2004) explained that attitude consists of three components, namely: a cognitive component, an affective component, and a conative component. The opinion of parents about the attitude of the language used at home in the family, in terms of aspects;

a) The cognitive component relates to knowledge about the environment and ideas which are usually categories used in thought processes.

b) The affective component concerns the matter of evaluating whether, like it or not, it is something or a situation

c) The conative component of the behavioral behavior or as the "final decision" act of reactive readiness to a situation.

Table 3. Parents opinion on language attitudes used at home in the family

\begin{tabular}{|c|c|c|c|c|c|}
\hline Category & $\begin{array}{l}\text { Strongly } \\
\text { Agree }\end{array}$ & Agree & Disagree & $\begin{array}{l}\text { Strongly } \\
\text { Disagree }\end{array}$ & $\begin{array}{l}\text { Average } \\
\text { Seore }\end{array}$ \\
\hline \multicolumn{6}{|l|}{ (Cognitive Aspects) } \\
\hline $\begin{array}{l}\text { Local language is an identity or identity, means of } \\
\text { comminication, and supports cultural development as well as } \\
\text { the languge of govemmert edueation }\end{array}$ & $23 \%$ & $40 \%$ & $30 \%$ & $0 \%$ & 1.16 \\
\hline $\begin{array}{l}\text { Indonesian is an identity or idenity, a means of } \\
\text { comminication, and a support for cultural development as } \\
\text { well as the language of goverment edueation }\end{array}$ & $45 \%$ & $16.3 \%$ & $20 \%$ & $0 \%$ & 1.02 \\
\hline $\begin{array}{l}\text { English is an identity or identity, a means of communication } \\
\text { and a sapport for cultural development as well as the languge } \\
\text { of government education }\end{array}$ & $33.5 \%$ & $3 \%$ & $11.3 \%$ & $35 \%$ & 1.04 \\
\hline \multicolumn{6}{|l|}{ (Aflective Aspects) } \\
\hline $\begin{array}{l}\text { Proud to be able to speak the local langunge which is } \\
\text { important for descendants, as well as to be more dignified, } \\
\text { modenize, and easy to absorb the information corveyed }\end{array}$ & $37.3 \%$ & $25 \%$ & $14 \%$ & $5 \%$ & 1.02 \\
\hline $\begin{array}{l}\text { Being proud to be able to speak Indonesian is inportant for } \\
\text { descendants, as well as being more diguified, moderizing. } \\
\text { and easily absorbing the informution comeyed }\end{array}$ & $30 \%$ & $13 \%$ & $40 \%$ & $0 \%$ & 1.04 \\
\hline $\begin{array}{l}\text { Being proud to be able to speak Engfish is important for } \\
\text { descendart8, as well as beirg more dignified, moderniaing. } \\
\text { and easily absorbing the information comeyed }\end{array}$ & $33.2 \%$ & $14 \%$ & $37.5 \%$ & $0 \%$ & 1.06 \\
\hline \multicolumn{6}{|l|}{ (Comtive Aspect) } \\
\hline $\begin{array}{l}\text { Local langunges make life suecessfil and confident, as well as } \\
\text { profitable and able to tnderstand the world }\end{array}$ & $10.0 \%$ & $19 \%$ & $45 \%$ & $12 \%$ & 1.08 \\
\hline $\begin{array}{l}\text { Indonesian makes people successfil in life and self-confidert, } \\
\text { as wel as profitable and able to understand the workd }\end{array}$ & $24 \%$ & $21 \%$ & $36 \%$ & $0 \%$ & 1.01 \\
\hline $\begin{array}{l}\text { English moles life successfil and confident, as well as } \\
\text { rewarding and being able to understand the world }\end{array}$ & $15 \%$ & $24 \%$ & $42 \%$ & $1.3 \%$ & 1.03 \\
\hline AVERAGE & $30 \%$ & $20 \%$ & $40 \%$ & $10 \%$ & 1.05 \\
\hline
\end{tabular}


Based on the percentage results above, the attitude of the parental language used at home shows "disagree" with the overall average percentage value of $40 \%$ or $100 \%$ of the expected, in terms of the aspect of language attitudes; Cognitive aspects: those related to knowledge, understanding, or belief in the function and benefits of the language. Affective aspects: which relate to the assessment of parents' language attitudes towards language used with children or families at home. Conative aspects: which relate to the tendency towards a language. From the above results and 30\% indicate a "Strongly Agree" attitude. Language is used at home with family or especially with children at home. And "agree" with a percentage of $20 \%$, while $10 \%$ for the "strongly disagree" scale. This shows that the attitude of the parents' language towards the language used with children or families at home "does not agree" to be adopted at home with the family.

Strongly contradicts or contradicts the scores for the average participant / respondent who answered that they were more inclined to local languages as identity, means of communication, and support for cultural development as well as the language of government education with the highest average score of other languages, namely 1.16 (cognitive aspects: knowledge, understanding, or belief in the function and benefits of language), and the average score, which is 1.06 of the participants / respondents said that they are proud that speaking English is important for offspring, and is more dignified, modernized, and easy to absorb the information conveyed (affective aspects: the assessment of the attitudes of the parents' language towards the language used with children or families at home) and the average score of 1.08 of the participants / respondents answered that English makes life successful and confident, as well as beneficial and can understand the world (conative aspect : relates to a tendency towards a language). With an overall average score of 1.05. This means that the attitude of the parental language towards language is contrary to the language adopted in the family at home and used with children so that here it is seen that local languages are believed to be the language used at home with the highest score, but by assuming English is more modern, dignified, and profitable for the future and the language which has a small percentage is Indonesian which is almost lost and is not trusted for the tendency in-home use and world modernization.

Thus attitudes have a very big influence and become a factor in the maintenance of a language and language shifts, as well as the language used in the family from the results of the measurement scale. This can be seen clearly in terms of attitudes or behavior towards the language which dominates the use of the mother tongue or the language of the region of origin of the family which can be maintained or maintained in the family.

However, the attitude of the parental language used or used with children at home, with family, provides a supporting result that "disagree" is indicated by a graph of the average overall score, as below;

Chart 2. The distribution of Parents' Language attitude

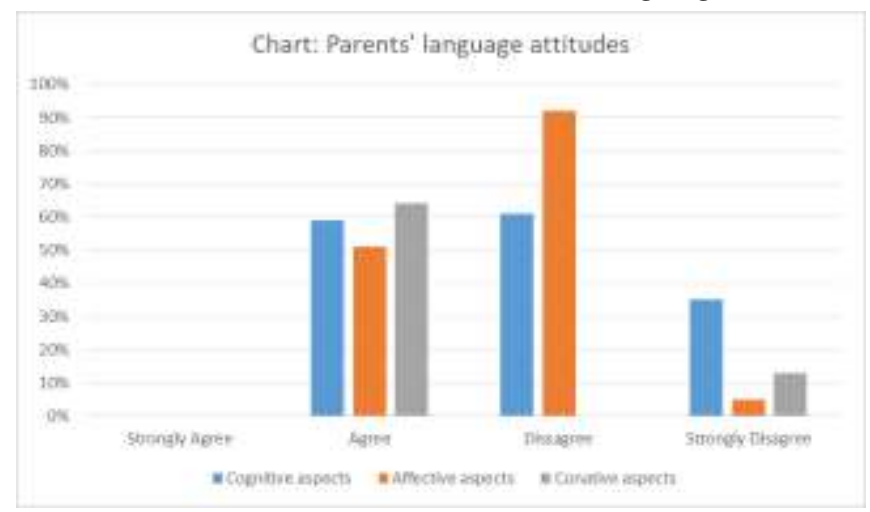


This study also uses direct observation methods on the research subject, namely parents. The observations were made in the realm of the family (at home). The data obtained is in the form of a list of statements in the form of the respondent's characteristics, the respondent's response. To screen for policies on family languages adopted by parents at home, and languages that coexist (or lose, or gain) in their family environment, and conduct semi-structured interviews with respondents. To find out the efforts parents are making to learn and maintain the language in their home. Interviews in the form of questions and answers about language attitudes and assessment of language and language maintenance.

The stages of this research are as follows; take care of the consent letter to be a respondent, make observations to the research location, take data in the form of a questionnaire to the respondent and recap the data that has been collected.

In this study, the researchers also collected data through interviews. An interview is a meeting of two people to exchange information or ideas through question and answer so that the meaning of a particular topic can be constructed (Esterberg, 2002). In this small study, the researcher used a semi-structured interview, namely this type of interview is included in the in-depth interview category, wherein its implementation is freer than a structured interview.

The purpose of this type of interview is to find problems more openly, in which the interviewee is asked for their opinion and ideas. Furthermore, the interview steps according to (LinCOlin \& Guba, 1985) state that there are seven (7) steps in using interviews to collect data in qualitative research, namely:

1) Decide who the interview will be conducted to

2) Preparing the issues that will be the subject of discussion

3) Starting or opening the interview flow

4) Carry out an interview flow

5) Confirming a summary of the results of the interview and ending it

6) Write down the results of the interview into field notes

7) Identifying follow-up interviews that have been obtained

The results of this qualitative research are to understand social reality, touch the praxis side, aim to build theories. Qualitative data in research obtained in this small study is exploratory in the form of writing, utterances, and even pictures/symbols. To analyze data like this, we do opencoding and axial-coding. Open-coding is finding key phrases in our data; axial-coding is determining the relationship between the themes that we have found in the open-coding stage. This study using the Grounded theory design. Grounded theory is a qualitative research design in which the researcher produces a general explanation (theory) of a process, action, or interaction that is formed by the views of the subject or participants (Creswell, 2013). The purpose of this grounded theory approach is that researchers can get out of the general picture and obtain or find a theory related to certain situations. According to him (Creswell, 2013) there are several main characteristics in this approach, namely;

1) Researchers focus on processes or actions in which they have different steps or stages and that occur from time to time

2) Researchers also seek to develop a theory of the process or action at the end.

3) Writing, namely being part of the theory development memo where the researcher writes his ideas as data so that they can be analyzed and collected.

4) The main form of data collection often occurs at the time of the interview, where the researcher continues to compare the data obtained from the participants on ideas related to the emergence of the theory.

5) Data analysis can be structured and follows an open category development pattern so that one category can be chosen to be the focus of the theory and can be continued with a further clear description, namely regarding additional categories (axial coding), to form a 
theoretical model, while pointing meeting categories into theory is called or selective coding (Maziyya, 2014).

The instrument in this semi-structured interview research is the researcher himself, meaning that the researcher determines the focus of his research, selects informants as data sources, performs data collection, assesses data quality, analyzes data, and draws conclusions on his findings. While the data collection technique is through interviews, and researchers use informal conversations; According to (Moleong, 2007) researchers and participants are involved in informal conversations and are family-friendly and take place scientifically so that participants are consciously or not provoked to reveal the information expected by the research without coercion. However, in this data analysis technique, researchers use grounded theory through three stages; namely, Initial coding: Line-by-line coding or Initial coding: Word-by-word coding followed by a focused coding process, the researcher analyzed this data (Charmaz, 2008).

Furthermore, the researcher continues a coding process called focused coding; that is, it requires a decision about which initial coding can make the most analytical meaning to make your data category clear and complete (Charmaz, 2008), meaning that in this analysis, it is by combining every code that appears from the data.

Tabel 4. Coding by interview semi-structured the data from a questionnaire about parent's attitudes towards language and parent's efforts in maintaining the language.

\begin{tabular}{cl}
\hline No. & \multicolumn{1}{c}{ Coding } \\
\hline 1 & $\begin{array}{l}\text { Bahasa daerah, dan Bahasa Indonesia digunakannya dengan keluarga dan } \\
\text { orang sekitar }\end{array}$ \\
\hline 2 & $\begin{array}{l}\text { Bahasa daerah, Nyaman, dimengerti, dipahami, budaya, Bahasa ibu, Bahasa } \\
\text { asli keluarga }\end{array}$ \\
\hline 3 & $\begin{array}{l}\text { Penting, bagus, ciri/khas daerah, jati diri, mudah dipahami, mempertahankan } \\
\text { produk lokal, budaya }\end{array}$ \\
\hline 4 & $\begin{array}{l}\text { Bahasa Indonesia dan Bahasa daerah, Bahasa pertama, bahasa ibu, Bahasa } \\
\text { nasional }\end{array}$ \\
\hline 5 & $\begin{array}{l}\text { Sarana/Alat komunikasi, bersosialisasi dalam menjalin kerjasama dan saling } \\
\text { banyak fungsinya dalam setiap aspeknya }\end{array}$ \\
\hline 6 & $\begin{array}{l}\text { Bahasa Asing atau Bahasa Inggris, Bahasa yang mendunia dan banyak } \\
\text { digunakan dalam kancah internasional. }\end{array}$ \\
\hline 7 & $\begin{array}{l}\text { Sangat Penting, agar mereka mengenal budayanya sebagai identitas/ciri asal } \\
\text { diri dari daerah nya }\end{array}$ \\
\hline 8 & Bahasa keseharian dari sejak kecil, mudah dan dapat dipahami \\
\hline 9 & $\begin{array}{l}\text { Dengan menggunakannya dalam kegiatan keseharian bersama orang sekitar, } \\
\text { dengan terus melestarikannya,bila perlu memperkenalkannya ke dunia luar }\end{array}$ \\
\hline 10 & $\begin{array}{l}\text { Kelebihannya : Mudah dipahami oleh pengguna Bahasa asalnya, sedangkan } \\
\text { kelemahannya : tidak dapat dipahami oleh lawan biacara yang bukan daerah } \\
\text { asalnya pun tidak popular seperti Bahasa internasional }\end{array}$ \\
\hline
\end{tabular}

(Coding by P1-P20) Bahasa daerah, dan Bahasa Indonesia digunakannya dengan keluarga dan orang sekitar. 
This was done to facilitate their children to practice their local language. Regarding the use of local languages at home, (Gomaa, 2011) states that the use of home language at home is one of the most important factors in maintaining the language because it continues to be used in everyday life.

(Coding by P1-P20) Bahasa daerah, Nyaman, dimengerti, dipahami, budaya, Bahasa ibu, Bahasa asli keluarga. Penting, bagus, ciri/khas daerah, jati diri, mudah dipahami, mempertahankan produk lokal, budaya, Bahasa Indonesia dan Bahasa daerah, Bahasa pertama, bahasa ibu, Bahasa nasional. Sarana/Alat komunikasi, bersosialisasi dalam menjalin kerjasama dan saling banyak fungsinya dalam setiap aspeknya. Bahasa Asing atau Bahasa Inggris, Bahasa yang mendunia dan banyak digunakan dalam kancah internasional. Sangat Penting, agar mereka mengenal budayanya sebagai identitas/ciri asal diri dari daerah nya. Bahasa keseharian dari sejak kecil, mudah dan dapat dipahami.

They agreed that their children should be able to speak the local language and parents should teach their children the local language because it can preserve their identity. Besides, they feel more comfortable using local languages. The following is the interview transcript. The transcript was the participant's response when asked why their children should speak local languages. According to him, it would be better if our children learn and master regional languages before learning foreign languages to tell about their culture. Based on the transcript, it can be seen that local languages can be a tool to preserve and share their identity and culture. So, language is not only a means of communication but also a tool to emphasize one's identity or uniqueness from others. This is in line with research conducted by (Cho, 2000). It is reported that language has a relationship with identity. Those with "strong HL (inherited language) competence" have a strong sense of who they are (i.e., proud of their culture and ethnicity), also portray their cognitive, affective, and conative aspects of language. (Chaer \& Agustina, 2004), both in terms of language use. Indonesian, and does not rule out foreign languages or English worldwide.

(Coding by P1-P20) Dengan menggunakannya dalam kegiatan keseharian bersama orang sekitar, dengan terus melestarikannya, bila perlu memperkenalkannya ke dunia luar. Kelebihannya: Mudah dipahami oleh pengguna Bahasa asalnya, sedangkan kelemahannya: tidak dapat dipahami oleh lawan biacara yang bukan daerah asalnya pun tidak popular seperti Bahasa internasional.

Referring to the transcript above, it can be seen that the parents are trying to preserve the local language as a cultural heritage, continuing to use it with their children; use regional languages at home, both to acquire and maintain the language or to stay in touch with their community, so parents do not eliminate regional languages as their cultural heritage, even though they know the weaknesses and strengths of a language, and many languages live and coexist around them, loyalty, and awareness of cultural heritage remains a priority.

\section{CONCLUSIONS}

Related to the objectives and findings of this study; Parent's language policies and language attitudes at home in the family can be concluded that:

The family language policy implemented by parents at home is frequent, meaning that based on the above percentage results, the policy regarding the language used by parents at home shows "Often" with an overall average percentage value of $50 \%$ or half of the expected $100 \%$ reviewed from the aspect of the language policy adopted; Language beliefs or ideologies, language practice, and language management. This indicates that the language policy adopted at home with the "Frequently" family is used. Meanwhile, based on the above percentage results, the attitude of the language used by the parents at home shows "disagree" with the overall average percentage value of $40 \%$ or $100 \%$ of the expected, in terms of the aspect of language attitudes; Cognitive aspects: those related to knowledge, understanding, or belief in the function and benefits of the language. Affective aspect: relates to the assessment of parents' language attitudes towards the language 
used with children or families at home. Conative aspect: relates to the tendency towards a language. Namely 1.16 (cognitive aspects: knowledge, understanding, or belief in the function and benefits of language), and an average score of 1.06 participants/respondents expressed pride that speaking English is important for offspring, and more than that, dignity, modern, and easy to absorb the information conveyed (affective aspect: assessment of parents' language attitudes towards the language used with children or families at home) and the participant/respondent's average score of 1.08 answered that English makes life successful and confident, and useful and can understand the world (conative aspect: related to the tendency towards a language). With an overall average score of 1.05. This means that the attitude of the parents' language towards the language is contrary to the language adopted in the family at home and is used with children so that it is seen that the regional language is believed to be the language used at home with the highest score, but assuming English is more modern, dignified and profitable for the future and a small percentage of the language is Indonesian which is almost lost and is not trusted for the trend of domestic use and world modernization.

This shows that the attitude of the language of the parents towards the language used by the child or family at home "does not agree" to be adopted at home with the family. Whereas language coexists based on the percentage that is slightly different from the average acquisition of participants/respondents who answer more inclined "planning to use everyday language in the local language at home with children at every family meeting with the highest first average score of 1, 65 and planning, the use of Indonesian, the second score is 1.59 and for planning the use of English at home with children in family gatherings the value is 1.45 . With the average total score added to 1.30, it means that the language used is close to all languages but most The high score is the regional language used daily with children, the language used at home with the family, but in terms of (or loss, or gain) in their family environment, the percentage is English which has a lower score than Regional Language and Indonesian.

So that parental policies also cause the loss or maintenance of the language. Meanwhile, the efforts made by parents in learning and maintaining the language in their homes based on the results of the interviews stated that parents always maintain and preserve local languages as cultural heritage languages by continuing to use them with children and their families at home. Parental policies in maintaining local languages can be seen from the attitudes and efforts of parents in helping their children to maintain local languages. Regarding attitude, it can be positive or negative. Attitudes are reflected in the decisions and actions taken. Therefore, a positive attitude directs parents to try to help their children in maintaining the language. Their efforts are to use the local language at home, equip their children with various sources both print and non-print, and stay in touch with local ethnic groups. To maintain the local language properly, there must be good cooperation between parents, schools, local government, and the community.

From the research results obtained between parent's language police and language attitudes at home in the family, so things the good as parents at home must be able to play a role in fostering and developing language skills in children so that children communicate actively and effectively in their future lives when the children start to mature. And I think, as a good citizen, I am required to always uphold Indonesian as the language of instruction without leaving the local language as the mother tongue. Moreover, as a prospective educator, it is appropriate to use Indonesian by the prevailing rules so that diglossia does not occur. Therefore, to anticipate the phenomenon of language extinction, smart and serious efforts are needed. This can not only be done by the government, but also by the ethnic community who speak these languages by maintaining their loyalty to their regional language so that it remains high so that language shifts do not occur which can eventually lead to extinction. Apart from various documentation efforts, studies from various perspectives and even efforts to revitalize languages that are in the process of extinction, efforts to turn Indonesian society into a multilingual society may need to be considered more seriously. That is, the community is expected to master three languages at the same time, namely 
Indonesian as the language of unity, English as the language of international relations, and its ethnic language to preserve the language and culture of the region.

\section{REFERENCES}

Alwi, H., \& Sugono, D. (2000). Politik bahasa: Risalah seminar politik bahasa. Pusat Bahasa, Departemen Pendidikan Nasional.

Bezcioglu-Goktolga, I., \& Yagmur, K. (2018). The home language policy of second-generation Turkish families in the Netherlands. Journal of Multilingual and Multicultural Development, 39(1), 44-59.

Chaer, A., \& Agustina, L. (2004). Sosiolinguistik: perkenalan awal. Penerbit PT Rineka Cipta.

Cho, G. (2000). The role of the heritage language in social interactions and relationships: Reflections from a language minority group. Bilingual Research Journal, 24(4), 369-384.

Djamareng, J., \& Jufriadi, J. (2018). Pengaruh Sikap dan Peran Orang Tua Terhadap Pergeseran Bahasa Luwu di Kalangan Anak-Anak Pada Masyarakat Luwu Kota Palopo. Palita: Journal of Social Religion Research, 1(1), 79-94.

Fasold, R. (1984). The sociolinguistics of society. Ch. 6. Language Attitudes, Oxford, Basil Blackwell.

Glott, R., Schmidt, P., \& Ghosh, R. (2010). Wikipedia survey-overview of results. United Nations University: Collaborative Creativity Group, 8, 1158-1178.

Gomaa, Y. A. (2011). Language maintenance and transmission: The case of Egyptian Arabic in Durham, UK. International Journal of English Linguistics, 1(1), 46.

Grenoble, L. A., \& Whaley, L. J. (2005). Language Endangerment and Language Maintenance, and: Language Death and Language Maintenance: Theoretical, Practical, and Descriptive Approaches. Language, 81(4), 965-974.

Kheirkhah, M., \& Cekaite, A. (2015). Language maintenance in a multilingual family: Informal heritage language lessons in parent-child interactions. Multilingual, 34(3), 319-346.

King, K. A. (2000). Language Ideologies and Heritage Language Education. International Journal of Bilingual Education and Bilingualism, 3(3), 167-184. https://doi.org/10.1080/13670050008667705

King, K. A. (2006). Child language acquisition. An introduction to language and linguistics, ed. by Ralph Fasold and Jeff Connor-Linton, 205-34. Cambridge, UK: Cambridge University Press.

King, K. A., Fogle, L., \& Logan-Terry, A. (2008). Family language policy. Language and Linguistics Compass, 2(5), 907-922.

Kircher, R., \& Fox, S. (2019). Attitudes towards Multicultural London English: implications for attitude theory and language planning. Journal of Multilingual and Multicultural Development, 40(10), 847-864. https://doi.org/10.1080/01434632.2019.1577869

Lou, N. M., \& A. Noels, K. (2018). Western and heritage cultural internalizations predict EFL students' language motivation and confidence. International Journal of Bilingual Education and Bilingualism, 1-15. https://doi.org/10.1080/13670050.2018.1508277

Park, S. M. (2013). Immigrant students' heritage language and cultural identity maintenance in multilingual and multicultural societies. Concordia Working Papers in Applied Linguistics, 4, 30-53.

Ricento, T. (2000). Historical and theoretical perspectives in language policy and planning. Journal of Sociolinguistics, 4(2), 196-213.

Spolsky, B. (2004). Language policy. Cambridge University Press. 